\title{
Globalization of China and Nigeria's Language Educational Policy: A Case Study
}

\author{
Lantana M. Usman \\ University of Northern British Columbia, Prince George, Canada
}

\begin{abstract}
The aim of this paper is to examine the implications of China-Nigeria economic/trade relations on international cultural education, through the adoption of Chinese language in Nigerian public and private primary and secondary schools. This study is based on qualitative educational orientation, and the exploratory literature review and descriptive case study designs. Qualitative content analysis was used to elucidate and include citations from the reviewed literature data, and for description of the case studies. Findings of the study show that China-Nigeria economic partnership re-shaped Nigeria's current language educational policy for inclusive international cultural education; promotion of global, peace, and citizenship education; development and improvement of language instructional centers and personnel; and improving implementation challenges as delivery mechanism on pedagogy, resources, time, and financial cost. The study will incite further research by African countries currently implementing Chinese language and culture curriculum in schools and adult education centers. Confucius Institutes' research and development units across Africa can undertake research and come out with a unified Chinese language policy for schools and centers across Africa, a means of sustaining China-Africa partnership. China-Nigeria partnership on language and cultural education in primary and secondary schools has not been researched in any conventional research format prior to this article. The paper will be of value in interdisciplinary studies as international, cultural, peace, global, language, history, and economics education; economics; globalization studies; modern history; Chinese and Asian studies; African studies; amongst others.
\end{abstract}

Keywords: language education, global political economy, Chinese philosophy, human development, economics of education, Africa, Nigeria, trade partnership

\section{Introduction}

Globalization is a popular catchword among economists, journalists, politicians, scholars, and other professionals across the world. The term is often used as a way of describing a supposed connection of production across world nations (Smith \& Doyle, 2002). A conceptual definition of globalization refers to the process in which "events, decisions, and activities in one part of the world can come to have significant consequences for individuals and communities in quite a distant part of the globe" (McGrew \& Lewis, 1992, as cited in Myers, 2001, p. 3). However, it is possible that the paradigms of globalization have polarized the global North and South and incited debates on the potential social and economic cost and benefits. Within educational discourse, some scholars conceptualize the process of educational globalization as the "glocalization" of

Lantana M. Usman, Ph.D., associate professor, School of Education, College of Arts, Social and Health Sciences, University of Northern British Columbia. 
educational sectors. In other words, education systems in a given area are evolving, without being "Westernized" in the covert principle of development (Burbules \& Torres, 2000; Lauder, Brown, Dillabough, \& Halsey, 2006; Walters, 1997).

The explanation is further assessed by south nation scholars as Zeleza (2002), who see the process of globalization for African countries as representing and ensnaring coercive structures that represent Western hegemony. These views are shared by other African scholars of comparative education and development. Some scholars have written:

Globalization of Africa (is) forceful. It is apparent that African nations have no choice when the forces of globalization arrive. In Africa, democracy and capitalism are the moving spirits behind the globalization phenomenoum (sic), which is paradoxical to the adult education (and allied education) movement ... through democracy, adult education has been re-liberated, and free market enterprise (has) reduced public spending on education. (Nafukho, Amutabi, \& Otunga, 2005, p. 138)

Others attempt to show how globalization creates debates on what development priorities should be and the serious implications for the education of teachers (especially in developing countries) (Barakett \& Cleghorn, 2008, p. 128), and for young and adult learners in Africa (Nafukho et al., 2005).

The current discourse on African globalization involves China, which showcased the monopoly of African trade and investments by investing in a \$200 million structure housing the African Union headquarters at Addis Ababa, Ethiopia; the gesture registers and facilitates Sino-African trade partnership, and linking Africa's present with the past (Mbamalu, 2013, p. 38).

In the case of Nigeria, over 100\% Chinese private and public investments exist (Shen, 2013, p. 9). Through economic partnerships, "China is fast building schools, hospitals, hotels and tailor made companies in Nigeria, an indication that it might not be in a hurry to call it quits with the "African giant"' (Mbamalu, 2013, p. 38).

The purpose of this article is to examine the implication of China-Nigeria economic/trade relations through socio-cultural perspectives of language education. The paper research preambles are based on qualitative educational orientation, using context analysis, exploratory literature review, and qualitative descriptive case study designs (Bogdan \& Biklen, 2003; Creswell, 2012). The approach allows authors to immerse in the secondary data derived from various literature sources, and to analyze the phenomenon in depth for a better understanding of the general context, and identification of major themes (Huberman \& Miles, 2002; Ryan \& Bernard, 2002). Case studies are selected to demonstrate different Chinese language implementation strategies, drawing strengths and challenges of the implementation process.

The first part of the article provides a synopsis of the China-Africa economic trade partnership, followed by an overview of Nigeria's language education policy on indigenous languages. The medium of instruction, language of the immediate community, and language of instruction required by the National Language Policy (1999) will be discussed. The National Policy of Education (NPE) $(1977 ; 1980 ; 2000 ; 2004)$ will be reviewed with respect to how it fits in with the current innovative language policy. The policy features a foreign language teaching program that gives educators an opportunity to teach the Chinese language in Nigerian public and private primary and secondary schools. The program can be implemented by paying specific attention to curricula policy challenges and learning outcomes. The concluding section will show how suggested educational policy options can sustain the teaching and learning of Nigerian and Mandarin languages as a pathway of promoting and sustaining the China-Nigeria partnership. A comparative approach will be taken with respect to the topic of globalization of education. 


\section{Synopses of China-Nigeria Trade and Educational Partnerships}

The emerging "giant" China is undeniably at the center of the explosion of Africa-Asian trade and investment. Shen (2013) added, “... Some Chinese manufacturers move to Africa in an attempt to penetrate trade barriers" (p. 23). Hence, trade partnerships represent a new advancement in South-South commercial affairs (Broadman, Isik, Plaza, Ye, \& Yoshino, 2007, p. 1). A quantitative parameter of China-Africa trade partnership is presented in Figure 1.

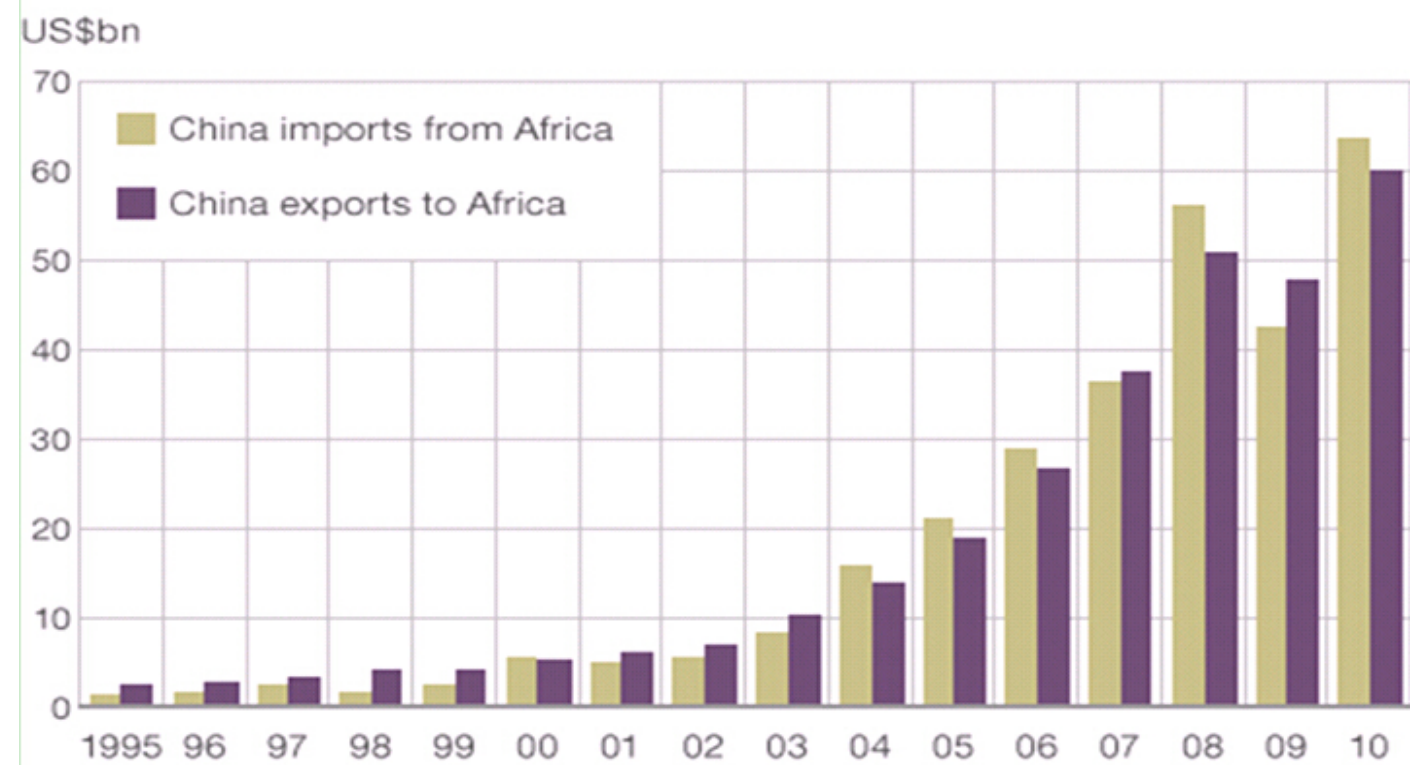

Figure 1. China and Africa's growing trade relationship (China Customs Data Frontier Advisory Analysis, 2011).

As of 2010, China's five top trading partners in Africa are Angola (U.S.\$24.8 billion), South Africa (U.S.\$22.2 billion), Sudan (U.S.\$8.6 billion), Nigeria (U.S.\$7.8 billion), and Egypt (U.S.\$7.0 billion) (China Customs Data Frontier Advisory Analysis, 2011).

Specific to Nigeria, a recent rebased Gross Domestic Product (GDP) ranked the country as the largest economy in Africa (Augie, 2014; Mohammed, 2014; National Bureau of Statistics (NBS), 2014). The new data estimated the Nigerian economy at N80.3 trillion (\$510 billion) for 2013 (NBS, 2014). A NBS report released on April 7, 2014, revealed diverse economic activities ranging from agriculture with about N17.26 trillion, trade N13.35 trillion, crude petroleum and natural gas N11.55 trillion, telecoms N6.97 trillion, real estate N6.43 trillion, manufacturing N5.47 trillion, food, beverages, and tobacco N3.70 trillion, finance and insurance N2.64 trillion, and motion picture, sound recording, and music production N1.13 trillion. The nine sectors listed above contribute $85.4 \%$ of the total GDP. Apart from being an unprecedented opportunity for both cultural and economic diplomacy in Africa, favourable reports attract China's interest in the Nigerian economy. According to the Consul-General of the People's Republic of China in Lagos, Liu Kan, in 2013 alone, China's non-financial direct investments in Nigeria stood at $\$ 1.79$ billion (about N293.5 billion). The investments are mainly from companies involved in free zone, petroleum, iron and steel, manufacturing, and agriculture; towards the end of the first quarter of 2014. Some Chinese investors who were on tour, said the country has indicated its readiness to invest about $\$ 300$ billion to boost Nigeria's economy (Augie, 2014). During the 24th 
World Economic Forum for Africa (WEFA) held in Abuja, Nigeria, China's premier Li Keqiang disclosed the Nigeria-China economic volume activities at 30.65 billion U.S. dollars (Mohammed, 2014).

The historical foundation of Asia-Nigeria trade relations began with the immigration of Hong Kong and Taiwanese people, who came to Kaduna City of Northern Nigeria, and founded manufacturing operations, particularly in textiles (present day Kaduna Textile Limited (KTL)) in the late 1960s to 1970s (Egbula \& Zheng, 2011). However, with increasing competition of cheap textile imports, many of these operations were forced to shut down. Their owners began to leave Nigeria, and in the late 1980s, they were replaced with a new generation of mainland Chinese investors. Bilateral trade between Nigeria and China can be traced as far back as 1969 with its total value recorded at approximately GBP2.3 million, climbing to GBP5 million in 1970 and GBP10.3 million in 1971 (Mthembu-Salter, 2009, p. 10). The historical data show that terms of trade were heavily in China's favour, with GBP4 million of the trade recorded in 1970 derived from Chinese textile exports to Nigeria (Mthembu-Salter, 2009, p. 10).

The president of the China Institution of Contemporary International Relations (CICIR) stated that since 2000, there has been an increased volume of trade between China and Nigeria in the neighborhood of $\$ 13.3$ billion (Oguntola, 2011). In Nigeria's oil and gas industry, China's investments are facilitated by the China National Offshore Oil Corporation (CNOOC). In 2006, Chinese businesses received four oil drilling licenses from Nigeria, and in return, the Chinese government invested $\$ 4$ billion in oil and infrastructure development projects. China has also expressed interest in buying a controlling stake in the Kaduna refinery in north central Nigeria, which has a daily production output of 110,000 barrels (Ogunmola, 2011). According to recent reports, the CNOOC has completed a GBP2.3 billion deal to buy a stake in a Nigerian oil field. The corporation has also received a huge loan granted by China for the building of three refineries in Nigeria (Oguntola, 2011). In 2005, Nigeria agreed to supply Petro-China with 30,000 barrels of oil per day $\left(4,800 \mathrm{~m}^{3} / \mathrm{d}\right)$ for $\$ 800$ million, and in 2006 , CNOOC purchased a share for $\$ 2.3$ billion in an oil exploration block owned by a former Nigeria defense minister. These trade initiatives consolidate China's access to crude oil for its energy needs back home. Unconfirmed reports indicate that China is now the second largest buyer of the nation's crude oil (Oguntola, 2011).

Across Nigeria, federal and state road and rail construction businesses are currently monopolized by the China Civil Engineering and Construction Corporation (CCECC). The firm has won federal and state contracts worth millions of dollars, with over 117 construction projects completed in Nigeria by the CCECC (Oguntola, 2011). Primary labor providers of Chinese construction workers in Nigeria are Chinese citizens, which is contrary to Nigeria's labor policy which requires an indigenous basic labor force. Critics have expressed the importation of Chinese labor practices as counter-productive and not fully beneficial to Nigeria, as few Nigerian workers earn a living from such huge projects. Other critics expressed their concerns on the characteristics of unskilled laborers imported by Chinese firms to Nigeria. Some have suggested that some of the workers might be prisoners back in China, which is not only a social security issue (Oguntola, 2011), but raises human rights concerns (Keenan, 2008). Nonetheless, the commitment of Chinese workers across Nigeria is commendable, as some of them in the course of performing their jobs and duties have been exposed to unnecessary violence, abuse, and torture, with some losing their lives in the ongoing inter-ethnic and religious conflicts in volatile areas of Nigeria (Isaiah, 2014; Somorin, 2014).

Further trade relations between China and Nigeria are promoted through cheap and affordable made-in-China products, ranging from cosmetics, mobile cell phones, computers and their accessories (available 
at the computer village in Ikeja, the capital of Lagos State), shoes and bags, textiles and clothing, etc.. Sources have reported that these goods are flooding local markets across Nigeria (Alao, 2010; Oguntola, 2011). Nigeria's highly price-sensitive consumers are picking China's imported goods without questioning their quality, thereby, swelling China's foreign reserves (Oguntola, 2011; Sonaiya, 2012).

Trade relations between China and Nigeria are focused on imports and exports, with records showing more Chinese imports to Nigeria, and less exports from Nigeria to China. The data seem to show Nigeria as a consumer nation of Chinese products, hence, creating a trade inbalance between the two nations (Oguntola, 2011; Sonaiya, 2012). Some observers criticize and interprete the trade inbalance (not only in Nigeria but across Africa) as the emerging face of "economic neo-colonialism" (Beuret \& Michael, 2008; Sonaiya, 2012).

In addition, Nigerian businessmen accuse China of exploiting tariff concessions to dump cheap goods in the local markets, and stifle competition (Beuret \& Michael, 2008; Sonaiya, 2012). Public critics, consumers, and traders have criticized the quality of some Chinese products. Commenting on the issue, one prominent Lebanese retailer in Kano observed:

I used to sell Chinese goods in my shop, but I stopped because they are so low quality. It is bad for my image. I have not actually seen any good quality Chinese material coming into Nigeria. The irony is that a lot of what I sell in this store actually comes from China, but it is high quality material, which we source, not from China, but from Europe. China sells higher quality material to Europe because of the standards they impose, whereas here in Nigeria, we are just a dumping ground for any kind of crap. (Mthembu-Salter, 2009, p. 21)

Nigerian and Chinese officials have argued over the problem of substandard and fake goods, of which limited attention has been provided to the trade "feud" by the Nigeria and Chinese governments and Chamber of Commerce (Egbula \& Zheng, 2011, p. 17; Lawan, 2010, p. 1). Indeed, the need for continous evaluation of Chinese products by Standard Organization of Nigeria (SON) is highly recommended for the safety of consumers, and for the promotion of business ethics and transparency.

Non-formal Chinese businesses, such as restaurants, are found in major Nigerian cities. Many of the patrons of these restaurants are middle and upper class Nigerians. The lack of lower class patrons are attributed to the high cost of meals, which are not affordable to lower income majority. The lower classes are thus not benefiting from these new Chinese local businesses. Nonetheless, some Chinese restaurants hire cheap indigenous laborers as cleaners, etc., while affluent indigenes use Chinese restaurants for business meetings, multicultural socialization, and a means of promoting cultural relations between Nigeria and China.

To regulate trade taxes between China and Nigeria, the two nations signed the Investment Promotion and Protection Agreement in 2001, and the Avoidance of Double Taxation and the Prevention of Fiscal Evasion Agreement (with respect to taxes on income) in April 2002, which is valid till date (China-Nigeria Relations, 2004; Premium Times Nigeria, 2012). However, recent reviews of the tax agreement revealed that some Chinese companies and businesses in Nigeria were involved with corporate tax malpractices. A Nigerian tax consultant explained how many Chinese firms are defaulting government in-tax remittance:

... The people are smart traders who have learnt the rope in many other countries. They offer falsified tax certificates or underpay to maximize profits. Unfortunately, many (Nigerian) government officials are part of the scam and Nigeria is losing billions yearly. (Oguntola, 2011, p. 1)

Critiques have suggested that Chinese firms also violate labor, union, and corporate laws (Oguntola, 2011). Unethical or illegal practices are also carried out by Nigerian traders through undocumented deals of 
unrecorded trade between China and Nigeria, particularly of Chinese imports. According to Sir Elvis Emecheta of the Nigerian-Chinese Chamber of Commerce:

Because of tax issues, companies prefer to keep quiet. It is hard to get the real figures, because most business is through the black market. They avoid the banks. Also, Nigerian companies are importing stuff from China that attracts high tariffs, so they are always under invoicing. Plus we have a liberal forex regime, so money flows in and out easily. All this means (that) the official trade figures will not be real. The real figures could be three or four times what is recorded. I am not exaggerating. Look, everyone who is going to China is buying $\$ 100,000$ or $\$ 200,000$ worth of goods, and people are going every week. They pay cash there and change the invoices. It is easy. (Mthembu-Salter, 2009, p. 11)

On trade behavior, it has been observed and reported that Chinese citizens in Nigeria, and Africa in general, often display unprofessional and "racist" behavior in the work place; with practices such as pay discrimination, disrespect of local labor unions, poor working conditions, poor pay, and lack of promotion to management levels for indigenous Nigerians, and indeed African workers (Egbula \& Zheng, 2011; Beuret \& Michael, 2008; Lawan, 2010; Sonaiya, 2012). In their defense, Chinese companies and businesses deny discriminating against Nigerian workers, arguing that salaries for both Chinese and Nigerian employees are low, but in line with pay rates in Nigerian companies (Egbula \& Zheng, 2011).

The additional impact of Chinese-Nigeria trade partnerships is noted in the development of street malls/markets in the China Town at Ojota, Lagos, in 2004, with an estimated 120 Chinese shops selling a range of manufactured goods, particularly clothes, shoes, and fashion accessories. Almost all of the merchandise that fills these shops is imported from China or produced by Chinese manufacturers in Nigeria (Egbula \& Zheng, 2011; Oguntola, 2011). The coming of the Chinese has appeared to result in an increased boom of property development/estate businesses. This increase of development has led to an increase in property values within major Nigerian cities. Oguntola (2011) stated:

Chinese are spreading their influence beyond trading borders. An estimated 100,000 Chinese are resident in Nigeria. They are in expensive estates in the commercial cities of Lagos, Port-Harcourt Kano and Aba. Magodo Estate in Lagos plays host to a sizeable Chinese. Residents complained that rents have skyrocketed since they started arriving. "Getting accommodation here now is tough. The Chinese are ready to offer triple whatever Nigerians struggle to offer" .... Checks revealed that getting a duplex in Magodo has shot up to between N2-2.5m per annum (U.S.\$12,296-15,370). (p. 1)

The ramifications of the China and Nigeria economic partnership involves intercultural education, with emphasis on language and culture, and the establishment of Confucius Institutes and Centers across Nigeria. One of the primary objectives of Confucius Institutes is to teach the Chinese language and culture to as many people as possible. Most Confucius Institutes across African nations have unified business and Chinese language curricula. Within the educational centers, students are taught about modern Chinese society, given detailed lessons on the Chinese language, Chinese expressions, Chinese texts, and conversational and listening skills (Confucius Institute of Kenyatta University, n.d). The educational curriculum content is unified and adopted in the primary and secondary Chinese language subjects in Nigeria, Kenya, Nigeria, Uganda, Malawi, etc., and other parts of Africa (Oluka, 2013).

The China-Nigeria intercultural educational partnership was founded with the establishment of a Confucius Institute at the University of Lagos on October 16, 2009, in conjunction with a partnership with Beijing Institute of Technology. Other Confucius Institutes and Centers are visible in Lagos, Kano, Cross River, and Anambra states in Nigeria. Some indigenous public critics have questioned the rationale, opportunity, and economic and social cost of implementing a new foreign language, at the expense of students' learning the 
three major indigenous languages: Hausa, Ibo, and Yoruba along with English (Onyeocha, 2014; Oyetade, 2001) as required by the NPE (Federal Republic of Nigeria (FRN), 2004).

Nonetheless, the foundation and implementation of the Chinese language in Nigerian primary and secondary schools have stirred educational policy debates that require an educational policy archeology, which serve as the nexus of this paper. The preceding discussion dwells on the synopsis of Nigeria's language policy on mother tongue, the language of the immediate community, the language of instruction, and medium of instruction (i.e., purpose and expected learning outcome). A narrative on the foundation, purpose, expected learning outcome, and curriculum policies and process of the Chinese language in public and private primary and secondary schools is presented. This narrative focuses on schools in Lagos, Kano, and Cross River State as case studies. In addition, the paper examines the challenges of implementing the Chinese language in educational structures, and concludes with suggested educational policy options that may serve as pathways of creating balance between teaching and learning in the mother tongue and implementing Chinese language as foreign language teaching in Nigeria's public primary and secondary students. The approach is referred as the "glocalization" of education in pluralistic societies, a means of embracing educational globalization without losing orthodox national value systems and direction (Barakett \& Cleghorn, 2008).

\section{Nigeria's Language Policy for Primary and Secondary Schools}

To promote the teaching and learning of indigenous languages or the mother tongue/the language of the immediate community, a National Curriculum Conference (NCC) was held in 1969, and later the National Conference on Education (NCE) in 1973, which led to addressing the issue in the first post-independence policy on education. The policy underwent several filters and approval processes, and was finally printed and made public in 1977 (Adaralegbe, 1972; Education Sector Analysis, 2003; Fafunwa, 1987; FRN, 2004), with subsequent revised editions in 1981, 1998, and 2004. In all the revised versions of the NPE, Section 1(8) emphasized the learning of indigenous languages or the mother tongue:

In addition to appreciating the importance of language in the educational process, and a means of preserving the peoples' culture, the government considers it to be in the interest of national unity that each child should be encouraged to learn one of the three major languages other than his own mother tongue. In this connection, the government considers the three major languages to be Hausa (North), Ibo (East), and Yoruba (West). (FRN, 2004, p. 9)

The stages of schooling and learning in the mother tongue begin from early years (pre-primary education), as stated in Section 2, Sub-section 11.3, "Government will ensure that the medium of instruction will be principally the mother tongue or the language of the immediate community" (FRN, 2004, p. 10); on primary education, Section 3, Sub-section 4 states, "Government will see to it that the medium of instruction in the primary school is initially the mother tongue or the language of the immediate community and, at a later stage English" (FRN, 2004, p. 13).

Regarding secondary education, Section 16, Sub-section 18-d states, "Secondary school should develop and project Nigerian culture, art and language as well as the world's heritage" (FRN, 2004, p. 16). Furthermore, the policy places an emphasis on core required secondary school subjects to include two Nigerian languages (NL2) at the junior secondary, and one Nigerian language (NL1) at the senior secondary (FRN, 2004, p. 17). Both NL1 and NL2 involve reading, writing, translation, practicals, and acculturation (Alao, 2010). The implementation of the NPE requires mother tongue or languages of the immediate environment be taught to all 
students in public and private schools. The requirement does not exclude private schools owned by Canadian, Turkish, American, British, French, or other foreign groups.

Further support for Nigerian students' learning of indigenous languages is reiterated in the 1979, 1989, and the revised 1999 Constitution of the FRN, Section 55, as well as the Cultural Policy for Nigeria (CPN) (1988, p. 49). However, the Nigerian Language Policy (NLP) emerged from the constitution of the FRN (1979; 1989; 1999), Section 51, and was developed to serve as a principled statement of the Federal Government of Nigeria, with statutory position of guiding the teaching, learning, and using the official and non-official use of different languages in the country (Mbah, 2012, p. 49). Scholars of Nigerian culture and languages have distinguished between Nigerian languages (NL) and languages in Nigeria (LIN):

NL are languages, which are indigenous to Nigeria by virtue of the fact that they are spoken by people, who hail from Nigeria and are legally Nigerians. LIN, on the contrary, are languages which are spoken within the shores of Nigeria irrespective of whether the speakers are legally Nigerians or otherwise. The NLP affects all the languages in Nigeria in one way or the other. The NLP targets Nigerian languages. However, because of the exigencies of the moment, namely, the multilingual nature of Nigeria, some languages in Nigeria, such as English, French, and Arabic, which are not Nigerian languages, are given official recognition until such a time one or some of the Nigerian languages mature by gaining wide acceptance to play the aforesaid official role. In other words, as long as the NLP does not produce an official language or languages, the languages in Nigeria which have been given official recognition will continue to play such official roles assigned to them. (Mbah, 2012, p. 49)

Indeed, Mbah further reiterated on languages spoken by people who are either illegal aliens, legal but non-naturalized persons, and naturalized persons whose mother tongues are not officially recognized, i.e., Chinese, Japanese, Fante, Zulu, Ewe, KiSwahili, and other languages whose speakers live in Nigeria. These languages (with the exception of the first three), though linguistically important, are not legally recognized in the NLP (Mbah, 2012, p. 49). Indeed, the author's citation of Chinese language minimizes its significance in the Nigerian language educational requirement, which raises questions on its inclusion in public and private schools in Nigeria.

To promote indigenous languages, the Federal Government of Nigeria undertook a cultural "renaissance" by establishing National Institute for Nigerian Languages (NINLAN) in 1991. The primary aim of the institute is for training and production of teachers of Nigerian languages for schools and public places (Chijioke, 2001). Other agencies in support of NINLAN include the Social Community Participatory Initiative (SCPI) program, facilitated by the National Institute of Cultural Orientation (NICO). NICO's primary responsibility includes the development of relevant curriculum, with the aim of promoting and integrating Nigeria's positive cultural values into the educational system at all levels (NICO, n.d.).

Strategies of implementing indigenous language curriculum in public and private schools in Nigeria involves the School-Based Implementation Approach (SBIA). The approach is embedded to the Bilingual Language Theory and Practice (BLTP), and the Subtractive/Early-Exit Model (SEEM) model. The model and theory allow the teaching of mother tongue as a subject of the curriculum, as well as medium of instruction and learning in early year's education (Fafunwa, 1987; FRN, 2004). The model is applied in pluralistic nations as Canada and U.S. (Tikolo, 2012). An early-exit transitional bilingual educational policy creates complication between the actual configurations of language use in Nigeria, and contradicts the implementation strategies in the nation's NPE. For example, due to environmental or geographic location of schools across the nation, most rural students do not attend pre-primary schools (as most of these schools are privately run and available in the 
cities and major towns) and are unable to learn in the mother tongue as required by the NPE (Tikolo, 2012, p. 12). This observation was supported by a report on how less than one in 10 children from the poorest $20 \%$ of households in Nigeria attend pre-school (United Nations Educational, Scientific, and Cultural Organization (UNESCO), 2003).

Despite systemic support in promoting Nigerian culture through indigenous language education, native language teachers across Nigeria continue to identify implementation inconsistencies that are facilitated by emerging educational language innovations or reforms. The inconsistencies have led to increased difficulties for educators trying to fulfil their instructional duties. The differences between public and private schools, as well as rural vs. urban schools allow autonomy, free choices, and decision of implementing mother tongue curriculum (Emenajo, 1998; 1996; UNESCO, 2003). The idea of private schools may seem good, but the reality is that the schools create educational gap that fosters inequality of access and learning between children of the haves and have nots. In addition, most parents with children in private schools prefer their children learn a foreign language, such as Chinese or French, in addition to the English language (Emenajo, 1996; Ogbonna, 2002; Osokoya, 2004). Parents' attitudes and choices challenge and frustrate teachers who are mandated to teach in the mother tongue as required by the NPE (Ogbonna, 2002; Osokoya, 2004; Oyetade, 2001). The implementation loophole allows the inclusion of foreign languages, as there are general notions that parents will teach their children the mother tongue at home, and in the community levels.

\section{Case Studies of Chinese Language Policy Implementation in Nigerian Primary and Secondary Schools}

China's African Policy (2006) Part IV 3:1 emphasized cooperation in education, science, culture, health, and social aspects. An excerpt from the policy states:

Cooperation in human resources development and education. The Chinese government will give full play to the role of its "African Human Resources Development Foundation" in training African personnel. It will identify priority areas, expand areas of cooperation and provide more input according to the needs of African countries so as to achieve greater results. Exchange of students between China and Africa will continue. China will increase the number of government scholarships as it sees fit, continue to send teachers to help African countries in Chinese language teaching and carry out educational assistance project to help develop Africa's weak disciplines. It intends to strengthen cooperation in such fields as vocational education and distance learning while encouraging exchanges and cooperation between educational and academic institutions of both sides. (China's African Policy, 2006, p. 1)

The above statement is a reality in Nigeria, with Chinese language adopted as part of the formal curriculum in some public and private primary and secondary schools (Affe, 2012; Aminu, 2013; Kano State Government, 2012; Odigboh, 2012; Olowoopejo, 2012; Osakwe, 2012). The inclusion of Chinese language is an inclusive international multicultural educational reform that embraces global education for global citizenship, social change, and development (Lauder et al., 2006). However, as of now, the policy of teaching Chinese language in primary and secondary schools is limited to the Nigerian states of Lagos, Kano, Cross River, and select private schools in cities. Implementation in these states is yet to be officially challenged by the Federal Ministry of Education central management, hence, receiving an unofficial "pass" or "approval" for the states involved. However, implementing the teaching and learning of Chinese language for Nigerian primary and secondary students has been, and is still highly criticized by some public observers, educationists, and culturalists in Nigeria and the Diaspora (Adeyemo, 2012; Awosiyan, 2012). Nonetheless, it is necessary to 
understand the aims, purposes, and objectives of teaching and learning of Chinese language by Lagos, Cross River, and Kano states.

\section{Lagos State}

Lagos State is the commercial seat of the nation, and the first state to officially adopt Chinese language as a subject of the curriculum across public and private primary and secondary schools. Ten public schools in Lagos State serve as pilot for the teaching and learning Chinese language as a formal foreign language subject (Oguntola, 2011). The reasons and justification of including Chinese language in Lagos State public schools was provided by the state governor as follows:

It is an economic decision from the government ... it would enhance the commercial skills of the pupils who will be the next generation of businessmen in the state; It is an economic decision. And the debate is now in the public domain. China economy is ranked among the first five economies today. They have started doing business in Nigeria and many African countries ... the introduction of the language would boost the state's economy, the government needed to move fast in line with global challenges and more importantly with China as an economic world power. ... The Chinese are in our homes more than we care to admit. Chinese have become our largest economic partner... Thus, it makes a lot of economic, social and political sense to prepare the younger generation of Nigerians who would be dealing with the Chinese and others with the necessary language power and proficiency to ensure that they do not suffer disadvantage in the global market... and there is need for us to understand that if we must engage countries with such economic potentials, we must learn their language urgently, if they (Chinese) can learn our local language with ease.... Governments often find it difficult to get Nigerians who can act as interpreters even at contract vetting sessions which often leave the state with the choice of employing Chinese to act as interpreters of documents prepared by the Chinese. (Blueprint Newspaper Editorial, 2012)

Further justification of including Chinese language curriculum is explained by the state commissioner for education:

... Learning Chinese language in Lagos schools has become necessary, because China has become the new destination for economic growth and technological development. (Blueprint Newspaper Editorial, 2012, p. 1)

The knowledge of Chinese language will help students to further their studies in China, and carry out research in various fields of human endeavor, as China has become a success story in the world economy, Lagos is the first Nigerian state to adopt the Chinese language as a curriculum in public schools. (Premium Times Nigeria, 2012, p. 1)

Even though the purposes, aims, and objectives of adopting and implementing Chinese language by Lagos State administrators attract public reactions (Olufowobi, 2012), the truth is that the reasons are "realities of global economic trends", especially with the strategic position and the rise of China as a world economic power. In support of Chinese language in public schools, African states as Kenya, Uganda, Malawi, and Zimbabwe are implementing Chinese language as a subject in primary, secondary schools, and tertiary levels, and providing the same reasons as Lagos State and other Nigerian states (Oluka, 2012).

Lagos State's Chinese language curriculum for schools involves partnership with the Confucius Institute at the University of Lagos. The use of Confucius Institutes and Centers was reiterated by Katherine Tweedie, Head of Africa at World Economic Forum, thus, "There is a need to create partnerships between African and Chinese universities to make it easier to learn not only the Chinese language but also the Chinese way of doing business" (Kimani, 2010, p. 1). The partnership with the University of Lagos Confucius Institute is to equip state schools with necessary logistics as instructional resources, and teacher training for the teaching and learning of Chinese language (Aboderin, 2012; Odigboh, 2012). The first Chinese language learning book Chinese Language Made Simple by a Nigerian author, Victoria Arowolo, made its first debut at the University of 
Lagos. The book, a self-study book for beginners to learn Chinese language, consists of the structure of Chinese syllable, Chinese phonetics, pronunciation guide, grammar structure, question pattern, and seven lessons which encompass nearly all communicative functions, such as greetings, making acquaintances, making enquiries, etc.. An audio disc is also attached to the book so as to enhance users' language proficiency (Xinhua News, 2012). About 1,000 copies of the book were printed at the first time, and half of them have already been booked by local secondary schools; Arowolo discovered the existence of communication gap between prospective businessmen and their Chinese counterparts and the inevitable need to understand the language of the world's most populous country, and second world economy (Xan, 2011).

On the training of Chinese language teachers, Lagos State partners with Confucius Institute and “.... holding Chinese Proficiency Test (HSK) examination, and tests for the certification of the Chinese language teachers, providing information and consultative services concerning China's education, culture, and so forth, conducting language and cultural exchange activities between China and Nigeria" (Oguntola, 2011, p. 1).

This progressive approach to instructional resource development and teacher training in Chinese language for Lagos public schools is innovative, considering the involvement of indigenous Chinese language teachers. However, there are no sufficient indigenous teachers to teach Chinese language, which forces some schools to hire Chinese economic immigrants (with no formal teacher training background) to teach Chinese language in public primary and secondary schools. The approach is considered a violation of the nations' National Teacher Council Standards (NTCS) (Federal Ministry of Education, 2011), and required standards on teaching of languages as indicated in Nigeria's NPE (FRN, 2004) and that of Association of Nigerian Language Teachers (ANLA) (Mbah, 2012). Even though Lagos State Government reiterated that students' learning of Chinese language is optional, but the ministry strongly recommend its learning, by providing "high" incentives to teachers and students (Aboderin, 2012).

\section{Cross River State}

The Nigerian costal state's decision to introduce Chinese language into the school curriculum was a conscious one, and justified by the state commissioner of education as thus:

As a state, we have lot of trade cooperation with the Chinese. We have also seen the movement of the West: Europe and America towards China. We believe that if we start teaching Chinese language in our schools, it will place our children on a very strong footing. It will also boost scientific and technical cooperation between the state and China. The advantage we will further have is that Cross River will be the first port of call for Chinese investments because of compatibility in language.... We strongly believe that the teaching of the language in our schools will really prepare us for the competition of the 21 st century. (Uzondu, 2012, p. 1)

The purpose and aim of the state embracing Chinese language curriculum is consistent with that of Lagos State, and other nations of Africa, such as Kenya, Uganda, and Malawi (Oluka, 2013). However, there seems to be a "copy-cat" approach of comparing the movement of the West towards China, which in the author's opinion, should not be, as nations have different national economic and political policies towards China.

With regards to training and hiring of Chinese language teachers, the Cross River State Government reiterated how Chinese citizens as language teachers will be and are hired through contact, partnership, and agreement with the Chinese Embassy in Nigeria, with some experts in Chinese language spending some time (teaching) in the state (Affe, 2012). In support of Chinese teachers' access to instructional facilities of teaching and learning Chinese language in public schools, the state commissioner of education added: 
We plan to convert the French Language Centre in Calabar into a foreign language center. The facilities used in teaching French can also be used in teaching any other foreign language. Gradually, we will roll it down to as many schools as possible, because we intend to have many indigenous experts in Chinese language (Uzondu, 2012, p. 1). Furthermore, the state commissioner of education extended partnership with Nnamdi Azikiwe University, Awka, which is currently collaborating with a Chinese university on the teaching of the language in the institution. (Affe, 2012, p. 1)

Cross River State's Chinese language policy and implementation are commendable, but critics question the cost involved in hiring, sustaining, and paying the Chinese teachers employed by the state government; as well as question the opportunity cost on the part of the government, students, and parents, and the effect it has on the promotion of Nigerian culture, which the state is known for in its yearly celebration of cultural carnival, a source of tourism and income generation for the state. Others question the extent to which the state government has actively facilitated the implementation of the mother tongue curriculum in the state's public educational system. The "language curricula overlapping" between languages of the community and Chinese language in Cross River State schools may require policy prioritization that will be sustainable and tangent to educational requirement.

System choice of Chinese language for schools in Cross River State is to strengthen the economic relation between the state and China. Indeed, China and Cross River State's bilateral trade has a long history, as noted by Xie Shao (Chairman of the Jiangsu Economic and Information Technology Commission, an investment arm of Jiangsu Province in China), who said:

They have been doing business in Cross River State in the last eight years, with heavy presence in the manufacturing of refrigerators, air conditioners as well as television sets, the state has become an investment haven for his company, hence the desire for further investments. (LEGISREPORTS NG, 2014, p. 1)

Sustaining Chinese investments in Cross River State is a priority (Cross River State Government, 2009; Ventures Africa, 2013), which facilitate the teaching and learning of Chinese language across public and private schools (Affe, 2012; Eyo, 2012; Mudiaga, 2012; Uzondu, 2012).

\section{Kano State}

The state is the commercial capital of Northern Nigeria, with huge Chinese investments. Hong Kong's Li Group of company in Kano State is said to have the highest number of employees in Chinese private company, with an estimated 7,000 employees out of the 20,000 nationwide employees, according to Kano trade unionists (Chinese People in Nigeria, n.d.). Kano State is the first northern state to adopt the teaching and learning of Chinese language in public primary and secondary schools. To facilitate the new foreign language in the planned curriculum, the state government sent 150 students to China to learn the language, as well as training of 30 teachers, with the hope that when they return home, they will form the backbone of the language training program (Blueprint Newspaper Editorial, 2012; News Agency of Nigeria (NAN), 2013). In promoting learning and teaching of Chinese language, the state governor stated:

... The state government would establish a special college for the study of Chinese language in Panshekara, Kumbotso Local Government Area of the state ... the state government had concluded the necessary arrangement with the Chinese government to train 30 teachers who would subsequently train more teachers before the take-off of the college in 2014. (NAN, 2013, p. 1)

As part of Kano State's educational transformation, the governor revealed how the state government sponsored 100 teachers to China for language classes (Kano State Government, 2012; RedCap Transformation, 
2013). While the state government is pursuing the teaching and learning of Chinese language through teacher training of indigenous teachers in China, it is leading local businessmen to China for bilateral trade with Chinese businessmen (Xinhua News, 2013). The state government's engagement with Chinese businesses is setting pace for northern states, of which many are getting involved across northern states, despite the ethno religious unrest of the region (Ismaila, 2012; Sani \& Sulaiman, n.d.). These economic benefits between Kano State and China are further facilitated with state government Chinese language policy, so as to create better business communication and development between the people and governments. Nonetheless, some Kano State indigenous businessmen and labor unions, are uneasy about the trend, and have accused the Chinese of killing throttling local industries through supply and manufacture of substandard goods and exploitation of their Nigerian workers (Lawan, 2010). The president of the National Harmonized Traders' Union (NAHATU) and former chairman of Kantin Kwari Market Traders Association, explained how Chinese achieved the feat of "hijacking" such a large stake in just six years, through sale of substandard goods and unethical business practices:

"After ordering the substandard goods from their home country, they act as wholesalers and retailers for the same goods in our local market. That puts them at a position which their Nigerian counterparts cannot compete with", the union leader added. "They have now become a threat to the survival of the local business and an obstacle to any attempt to revive our local industries". (Lawan, 2010, p. 1)

In addition, researchers' view was echoed by Dr. Ahmad Muhammad Tsauni of Bayero University's Economics Department, who claimed that:

The Chinese "bypass the principles" of globalization, by choosing to flood Nigerian markets with inferior goods. The economist observed that the Chinese were able to gain the upper-hand over their Nigerian counterparts because of their commitment to research and development on one hand, and the death of the manufacturing sector, especially in Kano, on the other. (Lawan, 2010, p. 1)

In addition, Kano Chapter of the Nigeria Labor Congress (NLC) is known to be having a running battle with some of the Chinese firms, over the non-implementation of the national minimum wage legislation, staff welfare, and unionism in accordance with the nation's labor laws (Lawan, 2010). Despite general trade irregularities between Chinese traders and companies and Kano State firms and private businesses and traders, the presence of the Chinese in the state is a priority for the state government's initiative of not only "welcoming" foreign investments, but ensuring their participation in trading and investments reduce unemployment rates in the state. Hence, learning Chinese language is a social index (educational) priority for sustaining trade relations between the two partners.

Significantly, some private schools across Nigerian cities include Chinese language as part of their school formal curriculum. Examples of private schools with Chinese language curriculum are Rantya High School in Jos Plateau State, and Grace International School, Lagos. The leadership of Grace International School Lagos justified its objective of including Chinese language curriculum, thus:

Chinese language was introduced so that the students could learn more languages to facilitate communication, and to have an added advantage, the need for students to acquire additional skills, in addition to their educational qualifications, as language skill is important. (Uchechukwu, 2010, p. 1)

Public observers and critics regard the teaching of Chinese language in private schools as "touch of elitism and class", thereby perpetuating inequality of access when compared to the poor rural children in Nigeria 
(Tooley, Dixon, \& Olaniyan, 2005), and educational disadvantages (Orekan, 2011). As noted in the studies of Ogbonna (2002) and Osokoya (2004), many parents with children in private schools across Nigerian cities prefer the use of English as medium of instruction, and less enthused on their wards learning the major languages of the community as required by the NPE. There is a more embracing attitude towards the learning of foreign languages than indigenous languages by parents and even the students (especially high schools) (Oyetade, 2001), which often is presented as novelty, elitism, and class.

What then are the curriculum and administrative challenges of implementing Chinese language to Nigerian students and teachers from preschool to secondary schools? These questions are addressed in the following discussion.

\section{Challenges of Implementing Chinese Language in Nigerian Schools}

So far, the implementation of Chinese language in Nigerian public and private schools has not only induced public criticism, but the program implementation experience challenges as pedagogical or delivery mechanism, access, availability, and applicability of instructional resources for learners and teachers, as well as administrative and logistics costs of hiring Chinese born teachers amongst other factors.

Pedagogical or delivery mechanism is a primary challenge of teaching Chinese language in Nigerian primary and secondary schools. Oral teaching and learning of Chinese language requires special "tongue twisting" technique (Wei, 2007). A Lagos based Chinese citizen language teacher, who used to be a middle school teacher in China several years ago, and currently teaches Chinese at three learning centers as the Lekki Foreign Language Training School and schools in Lagos State explained how teaching and learning Chinese language require frequent tongue twisting skills or mechanism (Wei, 2007). Chinese oral language tongue twisting mechanism is not only mentally demanding, but interferes with mother tongue accent, and the existing English language medium of instruction, thereby overwhelming Nigerian students in the course of oral communication flow, and undue cognitive pressure in the course of learning. The Lagos Lekki Chinese teacher concluded, "Nigerians take special interest in China and its brilliant culture, although the language is rather hard for them" (Wei, 2007).

Furthermore, Chinese language curriculum content is another major challenge. The language curriculum content includes numerals which are different from the English language format used by Nigerian students. Explaining the curricula learning dynamics, Odigboh (2012) added:

In Asian languages like Chinese, numbers after ten follow a precise logic. Eleven in Mandarin is shi yi or ten-one, twelve is ten-two, thirteen is ten-three, and so forth. When we get to fifty-nine, the logic continues, five-ten-nine. Five tens and a nine, 59. The internal logic in counting numbers with Asian languages results in kids who speak Asian languages are able to count beyond a hundred before English speakers can even count to 40. But the Asian language advantage does not stop in counting. Remember those dreaded fractions? In English, we would read 3/4 as three-fourths. But for languages like Chinese, $3 / 4$ is literally translated, "out of 4 parts, take 3".

These challenges, according to some Nigerian language teachers, are complicating the learning schemata of the students, as they are forced to adjust or co-switch between Chinese language curriculum and that of indigenous languages of Hausa, Ibo, and Yoruba curriculum, which is confusing, especially at the lower primary level of education. The curriculum demand of Chinese language requires learning adjustments and facilitation, thereby exerting extra learning motivation and effort of the learners, making language learning stressful, and sometime frustrating. 
Availability, usability, and affordability of instructional Chinese language resources is a huge teaching-learning challenge. Print and electronic textbooks are expensive, despite partnership with Confucius Institutes in Nigerian universities. Even though most private primary and secondary schools in Nigeria are able to afford these instructional materials due to their financial school fee income, public schools outside the selected schools implementing Chinese language are likely to struggle access and affordability of instructional resources, thereby creating learning imbalance between those who can afford and access instructional materials with those who cannot, hence, perpetuating educational inequality (Tooley et al., 2005).

Qualifications and teacher certification of Chinese citizens as language teachers in Nigerian public schools is an area of concern and a challenge. Organizations as Nigeria Union of Teachers (NUT) and Nigerian Language Teachers Association (NLTA) criticize the teaching credentials of some Chinese language teachers, especially Chinese economic migrants who by virtue of their nationality, and with no teacher training background, are employed by schools to teach Chinese language in Nigerian private and public schools, especially private schools. These organizations argue that Chinese language teachers in this bracket may not only lack basic classroom management, motivational theories, and practice approach required of a teacher in the course of curriculum delivery, but may be unaware of the "ways of knowing and learning" of Nigerian learners, which are grounded on cultural and traditional orientation of language learning (Aminu, 2013; Benson, 2004; Emenajo, 1996; Fafunwa, 1987).

Additionally, some indigenous public critics fear that such category of Chinese economic migrants turn language teachers (without adequate background checks for ethical and moral reviews so as to ascertain their suitability of teaching the youth) may be a security and safety challenge to the students they teach, especially in era of increasing fear of teacher pedophilia worldwide. However, interrogating this concern is applicable to China as well. Statistical data revealed a huge demographics of about 30,000 Nigeria economic migrants and their spouses in the Guangdong maritime and industrial area of China, with some of them teaching English language (without teacher training skills) in Chinese schools (Blueprint Newspaper Editorial, 2012). Further data on the practice were substantiated with the findings of Professor Taiwo of the Department of English, Obafemi Awolowo University, as follows:

I am aware there are already many Nigerian economic migrants in China who teach English in Chinese schools. These Nigerians are not necessarily Chinese speakers. Rather, their working knowledge of English has helped them to find relevance in China. I know Asian languages have limited domains of use and Asians are seeking opportunities to expand the domains of their language influence. If this policy is adopted, then the Chinese would have succeeded in achieving one of their long term goals. I hope however, that the commissioner's statement is not just a mere political statement. (Aboderin, 2012, p. 1)

From the above, it is clear that both China and Nigeria economic migrants take jobs of teaching the languages of their nationality, with most of them having less teacher training and professional skills, thereby challenging not only the professional teaching standards in both countries, but compromising safety and security of their students. Hence, China and Nigeria need to have a formal teacher policy on language teaching so as to address the challenges for students' safety, and quality of instruction that will yield positive learning experiences; these are reflected in the educational policy options section.

Further challenges of learning Chinese language were expressed by some Nigerian educationists as thus:

... We shall continue to produce future leaders who are incapable of thinking. The starting point should be the acquisition of the mother-tongue to enable the child think instead of confusing his (her) cognitive faculty with languages at 
an age he/she is just getting used to his/her first language. We are yet to solve the problem created by the wrong and untimely exposure of our children to some kind of English language. Why must we continue to complicate matters for our future for cheap political points? (Aboderin, 2012, p. 1)

Concerns of overwhelming Nigerian students with additional foreign language as Chinese was expressed by Nigeria's executive secretary of the National Institute for Cultural Orientation (NICO) thus: "We have not thought of learning and speaking our major Nigerian languages very well and we are thinking of learning Chinese" (Aminu, 2013, p. 1). Indeed, this view is the perception of most public critics against the maximization of foreign language curriculum at the expense of local languages for Nigerian children and youth, especially at the primary and secondary levels. The position is not only "protecting" and minimizing the chances of mother tongue extinction (Ogar, 2012; Onwubiko, 2007; Orekan, 2011), but ensuring that children and youth are not isolated from a major component of culture as language, but facilitate their "knowing" and sustaining indigenous languages for incoming generation (Fafunwa, 1974; 1987).

In sum, the teaching and learning of Chinese language in Nigerian schools are with challenges as noted above. These concerns have spurred debates on how the challenges can be minimized or "solved" as educational policy options, especially with supporters of Nigerian students learning Chinese language in Nigerian schools. These educational policy options are discussed in the following context.

\section{Suggested Educational Policy Options}

Typically, a policy is seen as a remedy for a social problem which develops somewhat like a "disease" requiring treatment (Scheurich, 1994). Indicators of common social problems in liberal policy frameworks incite the attention of the media, public critics, policymakers, and practitioners. In this context, educational change is considered an innovation for educational reforms at micro or macro levels, which may lead to policy solutions. This process which for the most involves an educational policy archaeology study that elucidates the social construction of the problems by interrogating social functions of policy studies, as related to agents of history; hence, what is seen as the problem is socially legitimized as a policy solution (Scribner, Reyes, \& Fusarelli, 1995).

Learning Chinese language in Nigerian schools is a contemporary progressive educational policy reform described as "... Education reform (that) ignores the history of education and takes a rhetoric definition of change. Scholars and policymakers have initiated education reform assuming that intervention is progress" (Scribner et al., 2008, p. 207). The term "progress" is what the Nigerian state governments associate the implementation of Chinese language in Nigerian schools, and for the quest and promotion of global education and citizenship. Davy (2011) added, "The world is changing, and there is evidence that we are entering a post-international environment: Borders are weakening, multiple citizenships are more common place, migration has reached record level, and we have encountered the death of distance" (p. 3). The growing curiosity of people in understanding and embracing different cultures, as well as understanding the how and why's of global events through education has increased between developed and developing nations. Andrzejewski and Alessio (1999) added:

By learning how global issues affect individual and community lives, how and why decisions are made which affect the planet and life on it, and, most importantly, means by which the future can be influenced, education can prepare students to become socially responsible global citizens. (p. 7) 
Indeed, the idea is featured in Nigeria's overall philosophy on living in unity and harmony and to "promote inter-African solidarity and world peace through understanding" (FRN, 2004, p. 6); while the nation's national educational goal that is derived from this philosophy reiterates "the training of the mind in the understanding of the world around" (FRN, 2004, p. 8).

Educational policy innovations are pathways that will remedy the teaching and learning challenges of Chinese language curriculum in Nigerian primary schools. First, pedagogical challenges as "tongue twisting" in oral Chinese language for Nigerian learners can be remedied with distance/virtual teaching innovation as cyber field trips (referred as classrooms "without borders"), where students from both countries engage in oral Chinese language conversations in a cooperative learning format, which facilitates critical learning analysis amongst students (Bandura, 1977). The model of cyber classrooms "without borders" is practiced in Canadian and United States (U.S.) school boards through partnership with cyber giants as Cisco, where elementary and secondary students engage in field trips with classrooms in China. Such a teacher-learner model can be used through the Nigerian Communication Satellite NIGCOMSAT-1 launched by China in 2007 with China's giant telecoms and network solution Zhongxing Telecommunications Equipment (ZTE) currently partnering with Nigeria's based Etisalat network (British Broadcasting Corporation (BBC), 2007; Xinhua News, 2013). One of the educational objectives of China's African Policy (2006) reiterated the need to promote distance education between China and African countries: “... China intends to strengthen cooperation in such fields as vocational education and distance learning while encouraging exchanges and cooperation between educational and academic institutions of both sides" (Part IV 3:1).

The advantage of cyber classrooms in learning oral Chinese language for Nigerian learners is that it will facilitate vicarious learning through imitation and observation, an educational language theory grounded on Social Learning Theory (SLT) of Bandura (1977) and the Zone of Proximal Development (ZPD) by Vygotsky (Tudge \& Moll, 1992). SLT describes verbal instruction/learning as an individual describes the desired behavior in detail, and instructs the participant on how to engage in the behavior; while symbolic of which modeling occurs by means of the media, movies, television, Internet, literature, and radio (SLT, n.d). Additionally, cyber classroom exchange programs will provide variety in learning, as well as cultivate friendship between Nigeria and Chinese students. Furthermore, the approach will reduce cost of hiring Chinese teachers, as well as easy access to Chinese home-based teachers for the Nigerian students.

To minimize the cost of "importing" qualified Chinese citizens as teachers by some states as Kano and Cross River, the use of one year graduate exchange programs between China and Nigeria can be undertaken. One year Chinese and English language graduate exchange program between China and Nigeria can be implemented. The exchange teachers will teach languages in primary and secondary schools in both countries, as done in the U.S. Fulbright Teacher Exchange Program. By so doing, both countries are assured of quality teachers, as well as learning consistency, and "safety" of their students, especially when the scheme is government approved. The international language exchange programs are common in Canada, with fresh Canadian graduates teaching English in China and other parts of Asia. British Columbia's Maple Leaf Educational Systems (MLES) is a pioneer service involved with recruiting Canadian students and graduates teaching English in China (Maple Leaf Educational Systems, n.d.). Such a model can be emulated by Chinese and Nigerian governments.

Considering the leading role of China in technology, partnership between Chinese and Nigerian local publishers should be facilitated in the production of affordable and cheap Chinese language e-books and textbooks. E-books are cheaper and handier than conventional textbooks. Furthermore, Chinese and Nigerian 
university researchers on Chinese language and culture should collaborate through research and innovations by developing instructional resources. By so doing, cost of production of materials will be minimized and accessibility increased. In addition, business collaboration between local publishers should be encouraged by the two nations. The publishing partnership will assist and increase cheaper production of Chinese language textbooks at all levels, and for the utilization in Nigerian classrooms.

Nigerian public and private schools should consider the use of language softwares as the Rosetta Stone "learning Mandarin or Chinese" for their students use, and the libraries. Using language softwares facilitates quick oral language development (i.e., improve the Chinese language tongue twisting skills for none Chinese learners), and allows individual private practice without feeling embarrassed when learning wrongly in open conventional classroom teaching and learning sessions.

In sum, the challenges of teaching and learning Chinese by Nigerian primary and secondary schools can partially be remedied through the aforementioned educational policy options. However, a more permanent "fix" solution will require consistent educational policy extensions and partnerships, financial support, and collective approval and participation of educational administrators and leaders, ministries of education, parents and teachers, and business personnel in China and Nigeria. The strategy will not only "open" further doors for partnerships between Chinese and Nigerian scholars, teachers, and publishers, but businesses in the area of instructional technologies and general educational matters.

\section{Conclusion}

The article provided a synopsis of China-Nigeria economic/trade partnership, with emphasis on the foundation and current state of trade partnership, and its impact on the promotion of cultural understanding through emerging educational innovation on Chinese language teaching and learning in Nigerian public and private schools in selected states as case studies. Further elucidation of the context provided a situational analysis of the national language policy in the NPE, relaying mother tongue processes and expected learning outcome for preschool to secondary school levels. The narrative followed an explanation of how and why selected public and private primary and secondary schools "embraced" Chinese language curriculum across Nigeria, which for the most aims at economic integration and global citizenship. The article reiterated general social economic advantages of China-Nigeria trade partnership, while the conclusion highlighted some challenges teachers and students in Nigerian primary and secondary schools are confronted with in the course of teaching and learning Chinese language as a curriculum subject; these challenges include pedagogical delivery mechanism of oral Chinese tongue twisting skills that exerts cognitive pressure, differences in language curriculum, lack of qualified Chinese teachers, cost of hiring Chinese citizens as Chinese language teachers, and cost and availability of Chinese language instructional materials. Suggested educational policy options include the need for both countries to engage in language teacher exchange programs, use of cyber classrooms to facilitate peer cooperative learning and better "tongue twisting" oral language skills, the inclusion of language and culture faculty researchers of universities in China and Nigeria for the development of Chinese language instructional materials that are simpler and affordable to Nigerian students, parents, and schools, and Nigerian business men and women travelling between China and Nigeria, and lastly, the use of computer-assisted softwares as the Rosetta Stone in basic Chinese language, as this will be available for students use and private learning.

Indeed, the rise of China in world economy is not only reckoned by the Nigerian government, but African 
nations, and the world at large (Alao, 2010; Osakwe, 2012; Mthembu-Salter, 2009; Shen, 2013). Questions, such as "Is China a friend or a foe to Africa?", are often raised, thereby, inciting public and academic debates by critics and supporters of the partnership, depending on the position one takes (Luo \& Zhang, 2014). Some critics view China-Africa partnership as China the "foe", and referring the partnership as "Chinese colonization of Africa" (Beuret \& Michael, 2008; Odigboh, 2012; Oguntola, 2011). The position of such critics may be related to their analysis of some political-economic behaviors of the Chinese on Africans and their systems, which are similar to previous colonialist of the continent. Indeed, other scholars of globalization reiterate the benefits of China-Nigeria/Africa partnership as "friendship" or China as a "friend" based on their synthesis of the economic dividend of the partnerships (Alao, 2010; Mbamalu, 2013; Mthembu-Salter, 2009; Osakwe, 2012; Oyeranti, Babatunde, Ogunkola, \& Bankole, 2010; Shen, 2013; Chen, 2010).

However, from the standpoint of this article, the acceptance, inclusion, justification, and measurable vantages of Chinese language by the selected state governments of Nigeria posits China as a "friend", as the educational partnership allows further social and economic cooperation for effective global education and citizenship. To sustain further economic transactions with China, Nigerian politicians and educational policymakers not only embraced the inclusion of Chinese language as part of educational change, innovation, and reform, but with the aim of preparing current and future generation of Nigerian students to actively engage with their Chinese counterparts in global development and peace sustainability (Nuredeen, 2013; Olufowobi, 2012). The author hopes that future research studies will be undertaken on or with similar phenomenon in a wider or comparative educational perspective.

\section{References}

Adams, O., \& Arowojolu, A. (2008). An evaluation of parents' patronage of private primary schools in Abeokuta, Nigeria. International Journal of African and African American Studies, 8(2), 58-70.

Adaralegbe, A. (1972). A philosophy of Nigerian education. Ibadan: Heinaman Nigeria Limited.

Aboderin, M. (2012, October 5). Planned introduction of Chinese language in schools stirs debate. PUNCH Online. Retrieved October 6, 2012, from http://www.punchng.com/education/planned-introduction-of-chinese-language-in-schools -stirs-debate/

Adeyemo, A. (2012). What are your thoughts on the planned introduction of Chinese language in the curriculum of Lagos State public schools? Retrieved January 5, 2014, from http://www.bellanaija.com/2012/09/11/what-are-your-thoughts-onthe-planned-introduction-of-chinese-language-in-the-curriculum-of-lagos-state-public-schools/

Affe, M. (2012). Cross River to introduce Chinese language in public schools. PUNCH Online. Retrieved December 6, 2013, from http://www.punchng.com/education/c-river-to-introduce-chinese-language-in-public-schools/

Akanfe, G. (2012). Lagos to introduce Chinese in public schools. Daily Times Nigeria. Retrieved January 5, 2014, from http://www.dailytimes.com.ng/article/lagos-introduce-chinese-public-schools

Akinnaso, F. N. (1993). Policy and experiment in mother tongue literacy in Nigeria. International Review of Education, 39(4), 255-285.

Alao, A. (2010). Chinese business interest and banking in Nigeria: African perspectives, global insights. South Africa Institute of International Affairs (SAIIA) Policy Briefings, pp. 1-4.

Aminu, A. (2013). NICO boss condemns introduction of Chinese language in Lagos schools. Daily Times Nigeria. Retrieved May 3, 2013, from http://www.dailytimes.com.ng/article/nico-boss-condemns-introduction-chinese-language-lagos-schools

Andrzejewski, J., \& Alessio, J. (1999). Education for global citizenship and social responsibility. Progressive Perspectives 1998-1993 Monograph Series, 1(2). Retrieved April 8, 2000, from http://www.UM.edu/glomono.html

Anyagafu, V., Sam-Duru, P., \& Saintjerry, N. (2014). Diaspora Nigerians contribute over 70\% in growing China economy. Vanguard (Nigeria Newspaper). Retrieved June 18, 2014, from http://www.vanguardngr.com/2014/06/diasporanigerians-contribute-70-growing-china-economy/\#sthash.wM0i2rOe.dpuf 
Augie, B. (2014). Chinese PM leads 100 man strong delegation, 12 African leaders also coming. Business Day Magazine (Nigerian). Retrieved April 29, 2014, from http://www.businessdayonline.com

Awolaja, A. (2012). Fashola's Chinese children. Retrieved December 19, 2012, from http://www.nigeriaintel.com/2012/11/21/ fasholas-chinese-children/

Awosiyan, K. (2012). Stakeholders disagree on teaching of Chinese in Lagos schools. Retrieved October 22, 2012, from http://tribune.com.ng/index.php/news/49544-stakeholders-disagree-on-teaching-of-chinese-in-lagos-schools

Bandura, A. (1977). Social learning theory. Oxford, U.K.: Prentice-Hall.

Barakett, J., \& Cleghorn, A. (2008). Sociology of education: An introductory view from Canada (2nd ed.). Scarborough, O.N.: Prentice-Hall.

Beckmann, A., \& Cooper, C. (2004). Globalization, the new managerialism and education: Rethinking the purpose of education in Britain. Journal of Critical Education Policy Studies, 2(2). Retrieved from http://www.jceps.com/?pageID=article\&article $\mathrm{ID}=31$

Benson, C. (2004). The importance of mother-tongue-based schooling for educational quality (Background paper prepared for the Education for All Global Monitoring Report 2005: The Quality Imperative). Paris, France: UNESCO.

Beuret, M., \& Michael, S. (2008). La Chinafrique: Pékin à la conquête du continent noir (China Safari: On the trail of Beijing's expansion in Africa). Paris, France: Grasset \& Fasquelle.

Blueprint Newspaper Editorial. (2012). Chinese language in Nigerian schools. Retrieved November 29, 2012, from http://blueprintng.com/2012/11/chinese-language-in-nigerian-schools/

Bogdan, R. C., \& Biklen, S. K. (2003). Qualitative research for education: An introduction to theories and methods (4th ed.). New York, N.Y.: Pearson.

British Broadcasting Corporation (BBC). (2007, May 14). China launches Nigerian satellite. BBC Africa. Retrieved May 21, 2014, from http://news.bbc.co.uk/2/hi/africa/6653067.stm

Broadman, H. G., Isik, G., Plaza, S., Ye, S., \& Yoshino, Y. (2007). Africa's silk road: China and India's new economic frontier. Washington, D.C.: The World Bank for Reconstruction and Development.

Burbules, N. C., \& Torres, C. A. (2000). Globalization and education: Critical perspectives. London, U.K.: Routledge.

Chen, S. R. (2010, December 23). China defends Africa economic trade role. Retrieved February 4, 2014, from http://www.bbc.com/news/world-asia-pacific-12069624

Chijioke, M. U. (2001). Politicization of education: Effect on the teaching and learning of Nigerian languages at pre-tertiary level in Nigeria. Nka, Journal of the Arts, 7-10.

China Customs Data Frontier Advisory Analysis. (2011). Viewpoint: Africa must do more to profit from China. Retrieved May 12, 2012, from http://www.bbc.co.uk/news/world-africa-18143515

China's African Policy. (2006). Part IV. Enhancing all-round cooperation between China and Africa. Retrieved May 28, 2014, from http://www.focac.org/eng/zt/zgdfzzcwj/t230479.htm

China-Nigeria Relations. (n.d.). In Wikipedia, the free encyclopedia. Retrieved May 21, 2014, from http://en.wikipedia.org/wiki/ China $\%$ E2\%80\%93Nigeria_relations

Chinese People in Nigeria. (n.d.). In Wikipedia, the free encyclopedia. Retrieved May 2, 2014, from http://en.wikipedia.org/wiki/ Chinese_people_in_Nigeria

CoDevelopment Canada. (n.d.). Globalization: Who is in charge of our future? Vancouver, B.C.: CoDevelopment Canada Association.

Confucius Institute of Kenyatta University. (n.d.). The Director-Confucius Institute, Kenyatta University, Nairobi. Retrieved May 27, 2014, from http://www.ku.ac.ke/confucius/images/stories/docs/brochure.pdf

Creswell, J. W. (2012). Qualitative inquiry and research design: Choosing among the five traditions (3rd ed.). Thousand Oaks, C.A.: Sage.

Cross River State Government. (2009). Report of the Vision 2020 Stakeholder Development Committee for Cross River State, Nigeria. Calabar: Cross River State Government.

Davy, I. (2011). Learners without borders: A curriculum for global citizenship. Cardiff, U.K.: International Baccalaureate Organization.

Education Sector Analysis. (2003). Historical background on the development of education in Nigeria. Abuja: Education Sector Analysis.

Egbula, M., \& Zheng, Q. (2011). China and Nigeria: A powerful south-south alliance. Retrieved from http://www.oecd.org/ countries/nigeria/49814032.pdf 
Embassy of the People's Republic of China in the Federal Republic of Nigeria. (n.d.). China-Nigeria relations. Retrieved April 2 , 2014, from http://ng.chinaembassy.org/eng/zngx/t142490.htm or http://ng.china-embassy.org/eng/

Emenajo, E. N. (1996). Languages and the national policy on education: Implications and prospects. Retrieved from $\mathrm{http}$ //fafunwafoundation.tripod.com/fafunwafoundation/id9.html

Emenanjo, E. N. (1998). Nigerian and foreign languages in education. In S. Oriafo, \& U. Gbenedio (Eds.), State of education in Nigeria. Lagos, Nigeria: UNESCO Lagos Office.

Eyo, C. (2012). Cross River dumps English for Chinese next year. Daily Trust (Nigerian newspaper). Retrieved January 9, 2014, from http:/www.dailytrust.com.ng/daily/old/index.php/education/47850-cross-river-dumps-english-for-chinese-next-year

Fafunwa, A. B. (1974). History of education in Nigeria. London, U.K.: George Allen.

Fafunwa, A. B. (1987). Education in the mother tongue: A Nigerian experiment. Journal of African Studies, 4(2), 285-299.

Fafunwa, N. B. (1990). Nigerian educational history. Journal of Educational Research and Development, 1(1), 52.

Federal Ministry of Education. (2011). Professional standards for Nigerian teachers. Abuja: Federal Ministry of Education.

Federal Republic of Nigeria (FRN). (1993). National Institute of Cultural Orientation. Retrieved from http://www.nico.gov.ng/

FRN. (2004). National policy on education (4th ed.). Lagos, Nigeria: NERDC Press.

Huberman, M., \& Miles, M. B. (Eds.). (2002). The qualitative researchers companion. Thousand Oaks, C.A.: Sage Publishers.

Isaiah, B. (2014, January 25). Gunmen kill Chinese worker, injured 2 others in Kaduna. Leadership Nigeria Newspaper Online. Retrieved March 4, 2014, from http://leadership.ng/news/340436/gunmen-kill-chinese-worker-injure-2-others-in-kaduna

Ismaila, L. (2012). Nigeria: As Lebanese, Indians retreat, Chinese fill the void in Kano. Daily Trust. Retrieved September 23, 2011, from http://allafrica.com/stories/201209090133.html

Kano State Government. (2012). Transforming education in Kano State: Governor Kwankwaso Agenda. Ministry of Information, Internal Affairs, Youth, Sports and Culture, Kano State. People's Daily. Retrieved March 7, 2013, from http://peoplesdailyng.com/transforming-education-in-kano-state-governor-kwankwaso-agenda/

Keenan, P. (2008). Curse or cure: China's investments in Africa and their effects on human rights. Retrieved from http://www.law.georgetown.edu/.../Keenan-Draft-Georgetown.pdf

Kimani, S. (2010, November 9). Interview: Learning Chinese language benefits China-Africa relations. Xinhua News (People's Daily Online). Retrieved November 3, 2013, from http://english.people.com.cn/90001/90777/90855/7193780.html

Kwankwasiyya. (2013). Kwankwasiyya Online. Retrieved December 8, 2013, from https://www.facebook.com/Kwankwasiyya Online/posts/675714175796531

Lauder, H., Brown, P., Dillabough, J. A., \& Halsey, H. A. (2006). Education, globalization, and social change. Oxford, U.K.: Oxford University Press.

Lawan, D. A. (2010, July 10). Chinese exploit us, threaten local industries-Kano bizmen. Weekly Trust. Retrieved June 1, 2014, from http://weeklytrust.com.ng/index.php/features/10648-chinese-exploit-us-threaten- local-industries-kano-bizmen

LEGISREPORTS NG. (2014, February 22). ODDITY: Chinese firms to invest $\$ 15$ million dollars in Cross River. Retrieved March 2, 2014, from http://legisreportsng.com/oddity-chinese-firms-to-invest-15m-in-cross-river/

Luo, J. B., \& Zhang, X. M. (2014). China in Africa: Devil or angel? Retrieved February 21, 2014, from http://www.nigeriamasterweb.com/paperfrmes.html

Maple Leaf Educational Systems (MLES). (n.d.). English as second language (ESL). Retrieved May 10, 2014, from http://www. mapleleafschools.com/homepage.php

Master Chinese. (n.d.). Nigeria publishes first Chinese-language learning book. Retrieved from http://www.masterchinese.com/ news/school-news/nigeria-publishes-first-chinese-language-learning-book.html

Mawhinney, E. H. (1995). Towards an archeology of policy that challenges conventional framing of the problem of violence in schools. Canadian Journal of Educational Administration and Policy, 2. Retrieved April 8, 2014, from http://www.umanitoba.ca/publications/cjeap/articles/mawhinney.html

Mbah, B. M. (2012). Language policy, mother tongue education and the role of the Nigerian language teacher in Nigerian language education. Journal of Education and Practice, 3(10), 48-54.

Mbamalu, M. (2013, May 12). Nigeria sneezes as China runs rings around Africa. The Guardian (Online Nigerian newspaper, Business section). Retrieved from http://odili.net/news/source/2013/may/12/3.html

Mohammed, A. (2014, May 8). Nigeria's bilateral trade volume with China hits $\$ 30.65$ billion. World Economic Forum for Africa (WEFA). The Guardian (Online Nigerian newspaper, Business section). Retrieved May 9, 2014, from http://www.ngrguardianews.com 
Mthembu-Salter, G. (2009). Elephants, ants and super powers: Nigeria's relations with China (Occasional Paper No. 42. China in Africa Project). Johannesburg, S.A.: South Africa Institute of International Affairs (SIIA), University of Witwatersrand.

Mudiaga, A. (2012, December 12). Cross River to introduce Chinese language in public schools. PUNCH Online. Retrieved from $\mathrm{http}$ //www.punchng.com/education/c-river-to-introduce-chinese-language-in-public-schools/

Myers, F. (2001). Introduction: The empire of things. In F. R. Myers (Ed.), The empire of things: Regimes of value and material culture (pp. 3-61). Santa Fe, N.M.: School of American Research Press.

Nafukho, F., Amutabi, M., \& Otunga, R. (Eds.). (2005). Globalization and adult education in Africa. In Foundations of adult education in Africa (pp. 134-146). Hamburg \& Cape Town: UNESCO Institute of Education Hamburg, Germany \& Pearson Education South Africa.

National Bureau of Statistics (NBS). (2014). April 2014 consumer price index \& inflation report of April 7 2014. Retrieved May 2, 2014, from http://nigerianstat.gov.ng/dataRelease

National Institute of Cultural Orientation (NICO). (n.d.). Objectives. Retrieved May 27, 2015, from http://www.nacd. gov.ng/nico.htm

News Agency of Nigeria (NAN). (2013). Kano sponsors 450 students in three private varsities-Kwankwaso. PUNCH Online. Retrieved December, 20, 2013, from http://www.punchng.com/news/kano-sponsors-450-students-in-three-private -varsities-kwankaso/

Nuredeen, A. N. (2013). Prospects, challenges of Nigeria-China business relation. Daily Trust (Nigerian newspaper). Retrieved January 8, 2014, from http://dailytrust.info/index.php/business/5248-prospects-challenges-of-nigeria-china-business-relation

Odigboh, R. (2012). Chinese colonization: Lagos State introduces Mandarin language in public schools' curriculum. Nigeria Education Blog/The Learning Craft. Retrieved March 4, 2013, from http://thelearningcraft.blogspot.ca/

Ogala, E. (2012). Lagos to teach Chinese in public schools. Premium Times. Retrieved from http://premiumtimesng.com/news/ 99701-lagos-to-teach-chinese-in-public-schools.html

Ogar, M. (2012). NICO's cultural fiesta underscores importance of indigenous languages. The Guardian (Online Nigerian $\begin{array}{lllll}\text { Newspaper). } & \text { Retrieved } & \text { April } & 17, & \text { from }\end{array}$ http://www.ngrguardiannews.com/index.php?option=com_content\&view=article\&id=108764:nicos-cultural-fiesta-underscor es-importance-of-indigenous-languages $\&$ catid $=80$ :education $\&$ Itemid $=610$

Ogbonna, S. O. (2002). Parental preferences for medium of instruction in primary schools: Implications for teaching in Nigerian languages. Journal of Basic Education in Nigeria, 1(1), 13-18.

Ogunjimi, J. T. (2013). Africa: The fading use of indigenous languages. Retrieved from http://saharareporters.com/article/africafading-use-indigenous-languages-ogunjimi-james-taiwo

Oguntola, S. (2011). How China is taking over Nigeria. The Nation. Retrieved December 10, 2013, from $\mathrm{http} / /$ www.thenationonlineng.net/2011/index.php/sunday-magazine/cover/24519-how-china-is-taking-over-nigeria.html

Olowoopejo, M. (2012). Nigeria: Why we introduced Chinese language in public schools-Fashola. Vanguard (Nigerian Newspaper). Retrieved October 3, 2012, from http://allafrica.com/stories/201210041159.html

Olufowobi, S. (2012, October 12). Lagos assembly divided over introduction of Chinese language. PUNCH Online. Retrieved October 14, 2012, from http://www.punchng.com/news/lagos-assembly-divided-over-introduction -of-chinese-language/

Oluka, B. H. (2013). Sing of the time. Kenya, Nigeria to introduce Chinese in public schools. The Observer-Education. Retrieved January 4, 2014, from http://observer.ug/index.php?option=com_content\&view=article\&id=27249\&catid=85

Onwubiko, C. (2007). Time to revive Nigerian languages. Business Day. Retrieved September 17, 2011, from http://www.businessdayonline.com

Onyeocha, U. (2014, February 26). Nigerian languages are in danger-Association cries out. Daily Times Nigeria.

Opiyo, O. (2010). Africa. Why Chinese should be taught in school. Business Daily (Nairobi). Retrieved May 28, 2014, from http://allafrica.com/stories/201008050106.html

Orekan, G. (2011). Mother tongue medium as an efficient way of challenging educational disadvantages in Africa: The case of Nigeria. Scottish Languages Review, 13, 27-38.

Osakwe, A. (2012). Exploring the complexities of China-Nigeria relationship: Is China good for Africa? International Affairs Review, 1(4), 7-20. Retrieved from http://www.usfca.edu/uploadedFiles/Destinations/Institutes_and_Centers/Pacific_Rim/ March\%202012,\%20Vol.\%201\%20Issue\%204.pdf

Osokoya, I. (2004). Parental preference for medium of instruction in Nigerian primary school education. Journal of Research in Education in Africa, 3(3), 133-142. 
Oxfam, G. B. (2006). Education for global citizenship: A guide for schools. Retrieved May 5, 2014, from http://www.oxfam.org.uk/ /media/Files/Education/Global\%20Citizenship/education_for_global_citizenship_a_guide_for_sc hools.ashx

Oyeranti, O., Babatunde, A. M., Ogunkola, O. E., \& Bankole, A. S. (2010). The impact of China-Africa investment relations: The case of Nigeria (AERC Collaborative Research China-Africa Project, Issue No. 8).

Oyetade, S. O. (2001). Attitude to foreign languages and indigenous language use in Nigeria. In H. Igboanusi (Ed.), Language, attitude, and language conflict in West Africa. Enicrownfit Publishers.

Premium Times Nigeria. (2012, May 24). Chinese investment in Nigeria hits $\$ 8.4$ billion-official. Retrieved from $\mathrm{http}: / /$ premiumtimesng.com/news/national/5282-chinese_investment_in_nigeria_hits_8_4_billion_-_official.html

RedCap Transformation. (2013, March 11). Education. These are some of the education oriented projects that the Government of Kwankwaso in Kano State has undertaking. Retrieved January 9, 2014, from http://www.redcapkano.com/projects/education/

Roberts, C. A. (1995). Bilingual education program models: A framework for understanding. The Bilingual Research Journal, $19(3$ and 4), 369-378.

Ryan, G. W., \& Bernard, H. R. (2002). Data management and analysis methods. In N. K. Denzin, \& Y. S. Lincoln (Eds.), Handbook of qualitative research (2nd ed., pp. 730-783). Thousand Oaks, C.A.: Sage Publishers.

Salami, O. (2008). It is still "double take": Mother tongue education and bi-lingual classroom practice in Nigeria. Journal of Language, Identity and Education, 2(2), 91-112.

Sani, M. B., \& Sulaiman, S. (n.d.). Structure of Kano economy. Kano Online. Retrieved July 1, 2014, from http://kanoonline.com/jmqs/index.php/component/content/article/37-economy/72-structure-of-kano-economy

Scheurich, J. J. (1994). Policy archeology: A new policy studies methodology. Journal of Education Policy, 9(4), 297-316.

Scholte, J. A. (2000). Globalization: A critical introduction. London, U.K.: Palgrave

Scribner, J. D., Reyes, P., \& Fusarelli, L. D. (1995). Education politics and policy and the game goes on. In J. D. Schribner, \& D. H. Layton (Eds.), The study of education politics (pp. 201-212). London, U.K.: Falmer.

Shen, X. (2013). Private Chinese investment in Africa: Myths and realities (Policy Research Working Paper 6311). Retrieved from http://led.co.za/sites/led.co.za/files/cabinet/orgname-raw/document/2013/6311.pdf

Smith, M. K., \& Doyle, M. (2002). Globalization. In The encyclopedia of informal education. Retrieved from http://www.infed. org/biblio/globalization.htm

Social Learning Theory (SLT). (n.d.). In Wikipedia, the free encyclopedia. Retrieved May 21, 2014, from http://en.wikipedia.org/ wiki/Social_learning_theory

Somorin, Z. (2014). Boko Haram operative kill Chinese worker, kidnap 10 in Cameroon. News Cameroon Online. Retrieved May 26, 2014, from http://www.cameroononline.org/2014/05/17/boko-haram-operatives-kill-chinese-worker-kidnap-10 -cameroon/

Sonaiya, R. (2012, October 8). China in Africa: Africans, beware! PUNCH Online. Retrieved from http://www.punchng.com/ opinion/china-in-africa-africans-beware/

Steiner-Khamsi, G. (Ed.). (2004). The global politics of educational borrowing and lending. New York, N.Y.: Teachers College Press.

Tikolo, O. (2012, December 21). English language incompetency amongst senior secondary school graduates in Nigeria. A-801: Education policy analysis and research utilization in comparative perspective. Retrieved January 6, 2014, from http://isites.harvard.edu/fs/docs/icb.topic1203150.files/Panel\%201\%20-\%20Teaching\%20in\%20Tongues/Olayide\%20Tikolo _Nigeria_English\%20Language\%20Incompetency_Final.pdf

Tooley, J., Dixon, P., \& Olaniyan, O. (2005). Private and public schools in low-income areas of Lagos State, Nigeria: A census and comparative study. International Journal of Educational Research, 43(3), 125-146.

Tudge, J., \& Moll, L. C. (1992). Vygotsky, the zone of proximal development, and peer collaboration: Implications for classroom practice. In J. Tudge, \& C. L. Molly (Eds.), Vygotsky and education: Instructional implications and applications of socio-historical psychology (pp. 155-172). New York, N.Y.: Cambridge University Press.

Uchechukwu, N. (2010, June 8). Nigeria: Grace schools begin Chinese language studies. Retrieved from http://allafrica.com/ stories/201006090154.html

United Nations Educational, Scientific, and Cultural Organization (UNESCO). (2003). The mother-tongue dilemma. Education Today. Retrieved from http://www.unesco.org/education/education_today/ed_today6.pdf

Uzondu, J. (2012, September 24). Why we introduce Chinese language in our schools. Retrieved from http://www.nigeriannews world.com/content/why-we-introduce-chinese-language-our-schools 
Ventures Africa. (2013). Chinese firm to open truck manufacturing plant in Calabar. Retrieved July 3, 2013, from http://www.ventures-africa.com/2013/05/chinese-firm-to-open-truck-manufacturing-plant-in-calabar/

Walters, S. (1997). Globalization, adult education and training: Impacts and issues. London, U.K.: Zed Books.

Wei, T. (2007, April 6). Chinese language fever in Nigeria. Retrieved from http://english.cri.cn/4026/2007 /04/06/44@213097.htm

Xan, R. (2011). Trade with China. Time for some language lessons. Retrieved May 28, 2012, from http://www.ft.com/cms/s/0/d4237ab6-1089-11e1-8298-00144feabdc0.html\#axzz330N5C8D4 and http://www.ft.com/home/ us

Xinhua News. (2012, September 9). China firm ZTE mulls telecoms venture in Nigeria. China Daily. Retrieved May 21, 2014, from http://www.chinadaily.com.cn/business/2012-09/27/content_15787911.htm

Xinhua News. (2013). Delegation from Nigeria's Kano state on tour of China. Global Times. Retrieved March 1, 2014, from http://www.globaltimes.cn/content/810671.shtml

Yusuf, A. (2014, January 19). China enlarges Nigeria's oil investments portfolio with N32b. Daily Independent. Retrieved from http://dailyindependentnig.com/2014/01/china-enlarges-nigerias-oil-investments-portfolio-with-n32b/

Zeleza, P. (2002). Rethinking Africa's globalization (Vol.1: The intellectual challenges). Trenton, N.J.: Africa World Press. 